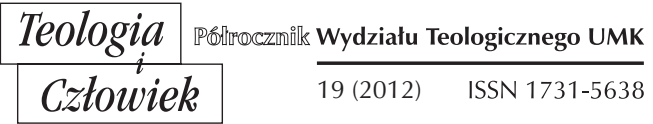

KS. KAZIMIERZ SKOCZYLAS*

WŁOCŁAWEK

\title{
WYCHOWANIE CHRZEŚCIJAŃSKIE WOBEC KULTURY
}

INDYWIDUALIZMU

\section{OKREŚLENIA INDYWIDUALIZMU}

Indywidualizm to określenie występujące $\mathrm{w}$ nauce, metanauce i filozofii lub postawa życiowa podkreślająca rolę jednostki w strukturze bytu $\mathrm{w}$ przyrodzie lub $\mathrm{w}$ życiu społecznym. Jest ona rozumiana często jako autonomia lub nawet opozycja wobec złożonych struktur sprowadzanych do prostych elementów, które stanowią podstawę wyjaśnienia natury lub funkcji całości ${ }^{1}$.

$\mathrm{Z}$ indywidualizmem spotykamy się $\mathrm{w}$ psychologii, etyce, socjologii, a także teologii.

Indywidualizm w psychologii oznacza orientację ujawniającą się w psychologii humanistycznej, która przyjmuje, że osoba ludzka ma w sobie wszystkie właściwości konieczne do osobistego rozwoju, a rola środowiska ogranicza się do stworzenia warunków umożliwiających aktualizację jej możliwości rozwojowych. On wyraża się też w silnym

* Ks. dr hab. Kazimierz Skoczylas - adiunkt w Zakładzie Katechetyki i Pedagogiki Religii Wydziału Teologicznego UMK w Toruniu.

${ }^{1}$ Por. S. Janeczek, Indywidualizm, w: EK, t. 7, k. 176-177. 
poczuciu podmiotowości i odrębności oraz w dążeniu do niezależności od społeczeństwa².

Indywidualizm w szczególny sposób charakteryzuje psychologów humanistycznych utożsamiających rozwój osoby z samorealizacją, a zwłaszcza C. Rogersa, według którego w każdym człowieku istnieje tendencja do samorozwoju i doskonalenia się. Stąd też tylko sam człowiek może według Rogersa określać cele, do których ma dążyć. Psycholog lub wychowawca powinien ograniczyć się do roli facilitatora. Polega ona na tworzeniu warunków umożliwiających jednostce samorealizację ${ }^{3}$.

Indywidualistyczna koncepcja osoby leży u podstaw niektórych kierunków psychoterapii. Jest ona istotna dla koncepcji terapii stworzonej przez wspomnianego Rogersa tzw. teorii terapii skoncentrowanej na kliencie i zapoczątkowanej przez Perlsa terapii Gestalt. Teoria terapii Gestalt stawia sobie za cel umożliwienie pacjentowi nauczenia się autentycznych form bycia, zgodnych z subiektywnym światem przeżyć, a nie ze społecznymi oczekiwaniami. W terapii tej ważne są tzw. grupy spotkaniowe, które dzięki dynamice grupowej i wzajemnemu zaufaniu mają stworzyć warunki do osobistego rozwoju i pozytywnych zmian osobowościowych uczestników ${ }^{4}$.

Indywidualizm ujawnia się również $\mathrm{w}$ pedagogice jako postulat wychowania niedyrektywnego. Wyraża się on we wspieraniu dzieci i młodzieży w rozpoznawaniu oraz realizacji możliwości rozwojowych, a także w skrajnej formie, jak ujmuje to antypedagogika jako rezygnacja z jakiegokolwiek wychowania ${ }^{5}$.

Jak zauważa Z. Zalewski, indywidualizm przejawia się również w relacji osoby do świata społecznego. Społeczność ludzką, z perspektywy indywidualizmu, traktuje się jako zbiór niezależnych jednostek, które powinny samodzielnie starać się o zaspokojenie swoich potrzeb. Akcentuje się tu także duża odrębność "Ja-inni”. Uwypukla się też przyjmowanie odpowiedzialności za własne działanie. W indywidualizmie przypisuje się samemu sobie zarówno sukcesy, jak i niepowodzenia. Prowadzi to do uzależnienia poczucia wartości od osobistych osiągnięć. Indywidualiści podejmują aktywność z własnej inicjatywy i dążą do osobistych celów. Zachowują też dystans i krytycyzm wobec środowiska

\footnotetext{
${ }^{2}$ Por. K. Kłysiak, Indywidualizm w psychologii, w: EK, t. 7, k 177.

3 Tamże.

4 Tamże.

5 Tamże
} 
społecznego i instytucji. Dla nich własny system wartości i przekonań stanowi kryterium ocen i decyzji. Więzi łączące ich z innymi mają najczęściej charakter kontraktu. Skrajny indywidualizm może prowadzić do instrumentalnego traktowania innych albo do konfliktów z istniejącym układem społecznym ${ }^{6}$.

W naukach społecznych indywidualizm jest elementem doktryny racjonalistycznej szkoły prawa naturalnego, teorii umowy społecznej a zwłaszcza ekonomiczno - społecznej koncepcji liberalizmu. Rozwiązania indywidualizmu dotyczące istoty i funkcjonowania społeczeństwa, państwa oraz życia gospodarczego wynikają z podstawowego założenia, że jednostka ludzka jest jedyną ontologiczną rzeczywistością. Jest ona traktowana jako jedyny i wyłączny podmiot życia społecznego. Jednostce przysługuje nieograniczona wolność obejmująca podmiotowość prawną, nienaruszalność w zakresie prawa własności oraz swoboda działalności gospodarczej. Interes jednostkowy jest wyłącznym kryterium celów społeczno - gospodarczych. Zasadą generalną w działalności gospodarczej jest wolny rynek i kapitał. Indywidualizm zakłada wiarę w ciągły postęp cywilizacyjny oparty na nieskrępowanej aktywności jednostek ${ }^{7}$.

Katolicka nauka społeczna odrzuca zarówno antropologiczne założenia indywidualizmu, jak i formy jego praktycznego zastosowania. Proponowana koncepcja człowieka nie uwzględnia jego społecznej struktury, a także funkcji. W szczególności krytykuje się go za amoralizm w odniesieniu do życia społeczno gospodarczego, uznanie człowieka za istotę egoistyczną i aspołeczną oraz absolutyzowanie jego wolności. Ten nurt stawia jednostkę w opozycji do społeczeństwa. Uznaje też konflikt między jednostką a władzą za nieunikniony. Identyfikuje on też społeczeństwo z państwowym systemem prawnym. Nie do przyjęcia z punktu nauki społecznej Kościoła jest także interpretacja naturalnego prawa własności utożsamianego z zabezpieczeniem jednostce absolutnej wolności posiadania. W konsekwencji to uniemożliwia korzystanie $\mathrm{z}$ prawa do używania dóbr i usług zgodnie z ich uniwersalnym przeznaczeniem. System prawny eksponuje jednostronnie uprawnienia jednostek bez uwydatnienia społecznego wymiaru praw człowieka. To zaś otwiera drogę do egoistycznej żądzy zysku i posiadania. To stwarza możliwość skupienia bogactwa w wąskiej grupie osób. Taka sytuacja musi prowadzić do

${ }^{6}$ Por. Z. Zalewski, Indywidualizm w psychologii, w: EK, t. 7, k 178.

7 Por. W. Piwowarski, Z. Skwierczyński, Indywidualizm w naukach społecznych, w: EK, t. 7, k 180. 
konfliktu między kapitałem a pracą przez zapoznawanie przysługujących pracownikowi uprawnień choćby do sprawiedliwej płacy, współrządzenia, korzystania z zysku, współwłasności ${ }^{8}$.

Indywidualizm jest pojęciem obecnym także $\mathrm{w}$ teologii. $\mathrm{W}$ sensie pozytywnym stanowi kategorię uzasadniającą godność osoby ludzkiej. $\mathrm{W}$ sensie negatywnym jest przejawem nieuwzględnienia społecznego wymiaru człowieka w duchowości chrześcijańskiej, duszpasterstwie oraz teologii pastoralnej i moralnej.

Indywidualizm jest charakterystycznym znakiem personalizmu chrześcijańskiego podkreślającego wartość indywidualnej osoby. Ma on swoje źródło w odkryciu właściwości przysługującej każdej osobie jako istocie stworzonej i odkupionej wyrażające się w powołaniu każdego człowieka do celu nadprzyrodzonego (do świętości). Chrześcijaństwo ma charakter indywidualny, podkreśla bowiem niepowtarzalny charakter i wartość każdej osoby ludzkiej. Ten charakter był też w niektórych nurtach duchowości motywem tłumaczącym koncentrowanie się na indywidualnym zbawieniu i wymagającym unikania wszelkich okazji do grzechu. Postawa ta prowadziła niekiedy do indywidualistycznie pojętej ascezy, która koncentrowała się na osiągnięciu indywidualnej doskonałości. Obowiązki wobec doczesnej społeczności były okazją do zdobywania indywidualnych zasług. Skrajnym przejawem indywidualizmu była deprecjacja świata traktowanego jako źródło grzechu. Postawie tej sprzyjało także zapoznanie społecznej natury Kościoła. Przy takim nastawieniu wszystko podporządkowane było kształtowaniu indywidualnej pobożności. Indywidualizm powodował, że duszpasterstwo pomijało wspólnotowy charakter sprawowanych sakramentów, zwłaszcza Eucharystii. One były traktowane jako okazja do prywatnej modlitwy, dla której okazją były sprawowane sakramenty ${ }^{9}$.

Współcześnie zdaniem s. Janeczka i S. Żyźniewskiego obserwuje się w teologii zarówno tendencję do przezwyciężania, jak i pogłębiania indywidualizmu. Pomniejszaniu indywidualizmu służy podkreślanie społecznego wymiaru zbawienia, które winno objąć całą ludzkość. Indywidualizmowi sprzyjają prądy podkreślające autonomię osoby, akcentujące role indywiduacji i indywidualizacji uznawanych za element formowania tożsamości osobowej. To przeradza się czasem w antropocentryzm i subiektywizm, które podkreślają w sposób skrajny autonomię sumienia oraz

\footnotetext{
8 Tamże.

9 Tamże, k. 181.
} 
rolę wolności osobowej nieskrepowanej normami moralnymi. Postawę tę postuluje kulturowa psychoanaliza, dla której rozwój osobowości nie jest celem domagającym się odwoływania do stałego wyposażenia naturalnego ${ }^{10}$.

Przejawem współczesnego indywidualizmu jest też częsta tendencja do określania istoty i zadań wiary chrześcijańskiej w kategoriach ideologii wbrew tradycyjnemu rozumieniu religijnej ortodoksyjności. Postuluje się prawo do samodzielnego wyboru zakresu prawd religijnych oraz przeciwstawianie indywidualnej wiary jednostki doktrynalno-kościelnej religii, czyli zinstytucjonalizowanym wyznaniom ${ }^{11}$.

Współczesne rozumienie indywidualizmu odnosi się najczęściej do „indywidualistycznie” zorganizowanego społeczeństwa, bądź do „indywidualistycznie" ukształtowanej jednostki ${ }^{12}$. Indywidualistyczne społeczeństwo rozpatruje się w opozycji do zasad organizacji społeczeństwa. Z kolei „indywidualistycznej” jednostce przypisuje się autonomię w podejmowaniu decyzji i formułowaniu kryteriów ocen. Podkreśla się tu, że jednostki nie orientują się już na określone tradycją normy i wartości, lecz odwołują się w coraz większym stopniu do swoich aspiracji i przekonań. Efektem tego jest znaczna różnorodność postaw, stylów życia i sposobów działania.

\section{ZASADNICZE ETAPY KSZTAłTOWANIA SIĘ OKREŚLENIA INDYWIDUALIZMU}

Termin indywidualizm stopniowo formował swoje znaczenie i wraz z upływem czasu różnicował się on.

Współczesność, zdaniem wielu socjologów (m.in. Nicolas Rose), zbudowana jest na założeniu, że jej podstawowym elementem jest jednostka nieskrępowana w swoich decyzjach i wyborach działań. W cywilizacji Zachodu indywidualizm i indywidualizacja traktowane są jako rodzaj czynnika wyjaśniającego ewolucję postaw wobec norm moralnych, a także przemian systemów wartości.

10 Tamże, k. 182.

11 Tamże.

12 Por. Z. Bokszański, Indywidualizm a zmiana społeczna. Polacy wobec nowoczesności. Raport z badań, Warszawa 2007, s. 7. 
Jego wpływ uwidocznił się także w przekształceniach form życia religijnego. Thomas Luckman jako jeden z pierwszych badaczy już $\mathrm{w}$ połowie lat sześćdziesiątych $\mathrm{XX}$ wieku zwrócił uwagę na zjawisko prywatyzacji religii, które jego zdaniem jest konsekwencją orientacji indywidualistycznych.

Obecność indywidualizmu przyczyniła się także do ożywienia debat na temat czynników integracji i zróżnicowania w życiu społecznym. Indywidualizm obdarza się odpowiedzialnością za wiele aspektów współczesności. Uwypukla się tu przede wszystkim egoizm we wszystkich przejawach, brak zainteresowania sprawami publicznymi tzw. „apatię polityczną", rosnącą liczbę rozwodów, załamanie się przyrostu naturalnego, nasilanie się aspołecznych zachowań, wzrastającą wyraźnie laicyzację. Charles Taylor pisze o skutkach jego w postaci „społeczeństwa permisywnego" czy eksplozji „narcyzmu”.

Dlatego pojęcie indywidualizmu stanowi przedmiot zainteresowania badaczy. Warto zauważyć, że jako pierwszy tom publikacji z badań nad wartościami przeprowadzony przez European Values Study (Halman 1987) był w znacznej części poświęcony indywidualizmowi.

Pierwsi terminu indywidualizm używali saint-simoniści. Użył tego terminu po raz pierwszy autor artykułu w 1826 roku w gazetce wydawanej przez saint-simonistów „Producteur”. Był on przez nich używany na określenie społeczeństwa zdominowanego przez konkurencję. Zaproponowali termin socjalizm jako określenie porządku społecznego sterowanego z centrum. Najczęściej więc indywidualizm był rozumiany w opozycji do kolektywizmu. Obecnie treści wiązane z pojęciem indywidualizm były łączone $\mathrm{z}$ efektami rozległego procesu modernizacji społecznej w XIX wieku. Zmiany te przyniosły ewolucję statusu jednostki. Proces ten prowadził do głębokich przekształceń więzi społecznej.

Pojęcie indywidualizmu było uzupełniane uogólnieniami płynącymi z obserwacji życia społecznego czynionymi przez socjologów XIX i XX wieku.

Opozycja pojęciowa indywidualizm-kolektywizm była źródłem podstawowych modeli indywidualizmu. Określenia „,indywidualizm-kolektywizm" były próbą opisania natury rzeczywistości społecznej, której natura była przedmiotem konfliktów. Problem dotyczy stosunku jednostki do zbiorowości, jej uprawnień i zobowiązań wobec różnorodnych całości społecznych.

Orientacja indywidualistyczna to pogląd zakładający, że całość społeczeństwa jest mniej wartościowa niż jednostka. Stąd całość spo- 
łeczna powinna być podporządkowana dobru jednostek i nie powinno się ograniczać ich wolności. U podłoża tych poglądów leży przekonanie sformułowane przez J. J Russo, że człowiek z natury jest dobry, a jednostka ludzka jest racjonalna i zdolna pokierować swoim zachowaniem.

Śledząc ukształtowanie się indywidualizmu w tradycji Zachodu, można mówić o dwóch podstawowych modelach indywidualizmu. Mówi się o modelu nawiązującym do Oświecenia bądź o modelu indywidualizmu nawiązującym do romantyzmu.

Oświeceniowy model „indywidualizm egalitarny” związany jest ze zdobywaniem niezależności w sferze publicznej we wspólnocie z innymi. Można go nazwać „indywidualizmem równej wolności”. Podkreślał on zasadniczą równość jednostek, poszukując w nich tego, co wspólne. Głosił, że jednostkowe cele można osiągnąć jedynie dzięki przestrzeganiu norm moralnych i racjonalnych reguł. To zmuszało do samodyscypliny i podporządkowania się woli większości. Spełnienie tych warunków miało zapewnić osiągnięcie szerokiego zakresu wolności pojmowanej jako przestrzeganie swobodnych wyborów jednostki realizującej rozumnie określone cele. Ten model indywidualizmu czerpie obficie z myśli J. Looka.

$\mathrm{Z}$ kolei romantyczny model indywidualizmu ekspresyjnego wynikającego z dążenia indywidualnego podmiotu do odkrywania i manifestowania własnej oryginalności. Indywidualizm ekspresyjny był antyegalitarny. Nie poszukiwał i nie sugerował istnienia wspólnych uprawnień i powinności. Sytuował jednostkę poza zbiorowościami. Tworzył świat jej suwerenności i podmiotowości poza normami społecznymi lub nawet przeciw nim. Z tej racji można go nazywać „indywidualizmem różnicy"13. Indywidualizm ekspresyjny ma swoje podłoże także w neohumanizmie XIX-wiecznym.

Indywidualizm jest też rozpatrywany w kontekście kulturowego zróżnicowania społeczeństw. Dychotomia indywidualizm - kolektywizm umożliwia poszukiwanie relatywnie trwałych, zakorzenionych w odrębnych kulturach i ugruntowanych normatywnie "indywidualistycznych" bądź "kolektywistycznych” wzorów wartości orientujących strategie życiowej działalności jednostek. Przyjmując taką perspektywę, uzyskuje się możliwość określania kultur indywidualistycznych i kultur kolektywistycznych. Pierwsza forma analiz to tendencja obecna na gruncie historii etnologii i antropologii kultury polegająca na konfrontacji wartości Za-

${ }^{13}$ Por. M. Środa, Indywidualizm i jego krytycy. Wspótczesne spory między liberałami, kom unitarianami i feministami na temat podmiotu, wspólnoty i ptci, Warszawa 2003, s. 54. 
chodu z cywilizacjami pozaeuropejskimi. Przez to starano się rozpoznać dystans kulturowy i poszukiwanie zrozumienia, co stanowi podstawę tożsamości cywilizacyjnej Zachodu. W epoce odkryć geograficznych było to eksponowanie chrześcijaństwa i chrześcijańskiego modelu wartości. W oświeceniu była to idea postępu cywilizacyjnego. Wiek XX stworzył nową płaszczyznę porównań. Stała się nim idea indywidualizmu i autonomicznej jednostki oraz idea demokracji i praw człowieka. Zainteresowanie indywidualizmem $\mathrm{w}$ XX wieku wiązało się także z pytaniem, jak kultura wpływa na zakres i sposób realizowania przez społeczeństwa procesu rozwoju społeczno-ekonomicznego i demokratyzacji życia politycznego. Skoro państwa odnoszą sukcesy gospodarcze, to charakteryzują się one jakimś typem ładu społecznego, który temu sprzyja.

Indywidualizm w porównawczych badaniach międzykulturowych bywa odnoszony do kultury narodowej bądź do szerszych całości kulturowych. Te szersze całości kulturowe nazywa się kręgami kulturowymi albo cywilizacjami.

Wszystkie społeczeństwa różnią się sposobami rozwiązywania swoich problemów. I właśnie odmienności owych rozwiązań przesądzają o odmiennościach kulturowych. Dążąc do opisu wspomnianych wyżej różnic, uwzględnia się następujące wymiary:

a) dystans wobec zwierzchności czy władzy (od małego do dużego), b) opozycja kolektywizm - indywidualizm, c) opozycja kobiecość-męskość, d) tendencja do unikania niepewności, e) orientacja długo- lub krótkoterminowa ${ }^{14}$.

Społeczeństwa indywidualistyczne to takie, w których dobro jednostki jest przedkładane nad dobro grupy. $\mathrm{W}$ takich społeczeństwa ma miejsce nieskrępowane wyrażanie opinii. Podkreśla się, że nie należy stronić od konfrontacji z opiniami i racjami innych. Także rodzina doświadcza konsekwencji indywidualizmu w społeczeństwie. Spoiwem rodziny kolektywistycznej jest lojalność jej członków. W rodzinie indywidualistycznej wyzwaniem do bycia lojalnym i do wypełniania zobowiązań jest własny interes i plany życiowe jednostki ${ }^{15}$.

W kulturach indywidualistycznych wszelkie spotkania stwarzają potrzebę do komunikowania się słownego. Cisza wydaje się czymś nienormalnym. W kulturach kolektywistycznych sam fakt współobecności innych członków wydaje się satysfakcjonujący, a rozmowa pojawia się

${ }^{14}$ Por. Z. Bokszański, dz. cyt., s. 25.

${ }^{15}$ Tamże, s. 25-26. 
wtedy, gdy istnieje potrzeba przekazania informacji. Tym, co różnicuje społeczeństwo kolektywistyczne od społeczeństwa indywidualistycznego, jest „kultura wstydu” i „kultura winy”. Społeczeństwa indywidualistyczne to społeczeństwa „kultur winy”. Jednostka przekraczająca normy społeczne ma poczucie winy, której źródłem jest intensywnie rozwinięta świadomość siebie. Społeczeństwo kolektywistyczne to kultura wstydu. Poczucie wstydu jest z natury zjawiskiem społecznym, zależy od tego, czy o przewinieniu wiedzą inni. Następna różnica uwypukla to, że w społeczeństwach kolektywistycznych osobiste relacje są ważniejsze od osiągnięcia celu. Natomiast w społeczeństwach indywidualistycznych relacje osobiste podporządkowane są osiągnięciu celu. Kultura, szeroko ujmując, to cywilizacja, która może być długowieczna albo krótkotrwała. Tym, co przesądza o trwaniu cywilizacji, to wspólny język i wspólna moralność, która z kolei zależy w ostateczności od przetrwania określonych podstawowych idei nadających strukturę ${ }^{16}$.

Problematyka indywidualizmu wpisana jest $\mathrm{w}$ zasadnicze różnice między cywilizacją Zachodu a innymi cywilizacjami. Na kształt indywidualizmu pewien wpływ wywarł protestantyzm. W myśli protestanckiej jednostka traktowana jest jako izolowana całość, która osłabia swoje związki z innymi dla poszerzenia zakresu swojej niezależności. W tej tradycji podkreśla się rolę świadomości własnych uprawnień przez jednostkę. Kulturę Zachodu można określić jako nisko zrytualizowaną. W kulturze Zachodu jednostka w niewielkim zakresie jest determinowana przez dokładnie określone rytuały. W efekcie stwarza to jednostce w kulturze Zachodu atmosferę swobody i komfortu psychologicznego ${ }^{17}$.

\section{INDYWIDUALIZM A NOWOCZESNOŚĆ}

Znaczenie indywidualizmu wiąże się z rozwojem nowoczesnego społeczeństwa. Nowoczesne społeczeństwo to społeczeństwo uprzemysłowione. Ważnym wymiarem nowoczesnego społeczeństwa był kapitalizm, czyli system wytwarzania dóbr. Jego elementem była konkurencja rynkowa i urynkowienie siły roboczej. W takim społeczeństwie kształtują się nowoczesne osobowości, które charakteryzuje indywidualizm. Tu jednostka jest uwolniona od narzuconych więzi grupowych

\footnotetext{
16 Tamże, s. 26.

17 Tamże, s. 30-31.
} 
od pokrewieństwa i innych struktur, sama ponosi odpowiedzialność za swoje decyzje. Tę osobowość cechuje też dyferencjacja, czyli wielość opcji w różnych dziedzinach życia, racjonalność, czyli stale odwoływanie się do rozumu, kalkulacji, obiektywności i efektywności. Następnym elementem charakteryzującym osobowość jest ekonomizm, czyli praca, produkcja i konsumpcja dóbr oraz ekspansywność rozumiana jako tendencja do rozszerzania się ${ }^{18}$.

Nowoczesność to pewna faza w rozwoju społecznym, która skończyła się w połowie XX wieku ${ }^{19}$. Tym, co sprawiło, że społeczeństwo można dziś nazwać "ponowoczesnym”, jest „aktywność w dążeniu do kontroli nad sobą oraz zmiana priorytetów w zakresie systemów wartości" ${ }^{\prime 20}$. Pierwsza nowoczesność nosi w sobie wpływy dokonań Oświecenia, druga natomiast rządzi się logiką przypływów, czyli wypełniania się sekwencją zjawisk nieprzewidzianych, wynikających z podejmowania decyzji.

Pojawienie się ponowoczesności poprzedziło wiele zjawisk i procesów w sferze kultury symbolicznej w przekonaniach światopoglądowych oraz strukturach społecznych i gospodarczych. $\mathrm{W}$ trakcie tego procesu praca traciła swoje centralne znaczenie. Jej miejsce zajęła wolność jednostki. W stosunku do innych dziedzin życia praca stała się mniej ważna i ograniczona do podrzędnej pozycji. To ma konsekwencje dla kształtowania jednostek. Jednostki te są zazwyczaj kształtowane do wypełniania roli konsumenta i gracza ${ }^{21}$.

\section{MODELE INDYWIDUALIZMU „PÓŹNEJ PONOWOCZESNOŚCl”}

Poszukiwanie swoistości indywidualizmu późnej nowoczesności jest dość trudne, przegląd bowiem literatury wskazuje na wiele ujęć tej rzeczywistości. Omawia się w niej nie tylko indywidualizm, ale indywidualizmy. Wynika to z różnorodności związanych z indywidualizmem sfer życia. Występuje tam wielość orientacji światopoglądowych i politycznych. Stąd pojawia się wiele terminów jak indywidualizm radykalny, egoistyczny, utylitarny, narcystyczny, republikański, liberalny, liberta-

${ }^{18}$ Tamże, s. 35-36.

${ }^{19}$ Por. M. Ziółkowski, „Uniwersalne wartości” a regionalne doświadczenia. Europa Środkowa wobec wspótczesnych zachodnich debat o wartościach i celach rozwoju, w: Porządek społeczny a wyzwania wspótczesności, red. A. Sakson, Poznań 2005, s. 158.

${ }^{20}$ Por. Z. Bokszański, dz. cyt., s. 38

${ }^{21}$ Por. Z. Bauman, Wolność, Kraków 1995, s. 91. 
riański, arystokratyczny i inne. Wielość koncepcji wynika ze sposobu udzielania odpowiedzi ze względu na swoistość tego indywidualizmu późnej nowoczesności. Najzwięźlej, zdaniem Z. Bokszańskiego, można określić jako konstruowanie pojęcia indywidualizmu na podstawie jego zakładanych czy z nim wiązanych skutków społecznych. Stąd też poszukiwanie jego skutków w wielu obszarach życia społecznego. Za takimi działaniami metodycznymi kryją się pewne założenia światopoglądowe i oceny moralne. Są to przekonania nadające indywidualizmowi status przyczyny obserwowanych zjawisk ${ }^{22}$.

Inna droga porządkowania wiedzy o indywidualizmie późnej nowoczesności polega na konstruowaniu modeli indywidualizmu właściwych dla późnej nowoczesności. Wybierając tę drogę odnosi się charakterystykę indywidualizmu nie do postulowanych skutków ale do ogólniejszych wymiarów czy aspektów samego indywidualizmu a mianowicie do relacji jednostka - społeczeństwo. Wymiary te zarysowują się dość wyraźnie w głównym nurcie debat teoretycznych i rozstrzygnięć metodologicznych. W wyniku takiego podejścia można traktować indywidualizm jako ciągle obecną w nowoczesności tendencję mającą ogólnie zakreślone gwarancje instytucjonalne a zorientowaną na poszerzanie przestrzeni suwerenności jednostki i autonomii jej działania. Charakterystyka swoistości „nowego indywidualizmu” mogłaby polegać na mierzeniu „przyrostów” niezależności czyli poszerzaniu się prerogatyw jednostki ${ }^{23}$.

Drugim aspektem transformacji „indywidualizmu późnej nowoczesności" jest zmiana funkcji indywidualizmu, a ściślej funkcji przypisywanych indywidualizmowi w doświadczeniach działających podmiotów. Indywidualizm przestał pełnić funkcje środka w organizowaniu ludzkiej aktywności, a stał się celem aspiracji i dążeń. W wyniku ewolucji indywidualizmu w społeczeństwach Zachodu nastąpiło przejście od przewagi wartości nakazujących samodyscyplinę, ograniczenie dążeń hedonistycznych i konformizm wobec norm własnej zbiorowości do pluralizmu orientacji normatywnych, ukształtowania się postawy permisywności wobec odstępstw od regulacji społecznych i otwartości na nowe zarysowujące się idee ${ }^{24}$. W wyniku tych przemian docenia się tolerancję dla odmienności i mniejszości, dla pluralizmu orientacji normatywnych, dla postawy permisywności wobec odstępstw od regulacji społecznych.

\footnotetext{
${ }^{22}$ Por. Z. Bokszański, dz. cyt., s. 50.

${ }^{23}$ Tamże, s. 50-51.

${ }^{24}$ Tamże, s. 49-51.
} 
Te dostrzeżone różnice ujęć stały się podstawą dla przyjęcia określeń „indywidualizm ekspansywny” i „indywidualizm samorealizacji” ${ }^{25}$.

Indywidualizm w pierwszej nowoczesności był zastrzeżony tylko do niektórych sfer życia (praca, produkcja, wymiana gospodarcza, obieg pieniądza). Natomiast w pracach Miltona Friedmana zauważa się już, że żaden obszar życia nie pozostaje już na zewnątrz rynku. Jest tylko jeden wymiar życia społecznego a mianowicie ten zdefiniowany przez egoistyczne działania (Lasch 1997, s. 104). Zjawisko rozszerzania się indywidualizmu dostrzegł najpierw J. Dewey. Główne spostrzeżenie Deweya stanowi przekonanie o nieuzasadnionym a co gorsza szkodliwym rozprzestrzenianiu się wpływów idei indywidualizmu. Jego zdaniem pojęcie indywidualizmu występuje aż w siedmiu odmianach. Mówi on o indywidualizmie moralnym, praktycznym, biologicznym, politycznym, ekonomicznym, psychologicznym, i metafizycznym. Kryzys nowoczesności wynika $\mathrm{z}$ tego, że w jej obrębie pojawia się szkodliwa ekspansja indywidualizmu. Efektem tej ekspansji jest wiele negatywnych zjawisk, które powodują, że w życiu mamy do czynienia z „zagubioną jednostką". Prowadzi to też do ograniczenia pola decyzji i aktywności jednostki. Jest to szczególnie widoczne w zakresie działalności gospodarczej. Innym wymienianym przez Deweya skutkiem indywidualizmu ekonomicznego i psychologicznego jest ich dominacja na wszystkich obszarach życia nie wyłączając kultury. Konsekwencją ekspansji indywidualizmu jest standaryzacja i konformizm a $\mathrm{z}$ drugiej strony zagubienie jednostek, nieład moralny, bezprawie związane $\mathrm{z}$ eliminowaniem determinant ludzkiego działania ${ }^{26}$.

O ekspansji indywidualizmu pisze też Peter Berger. W wyniku istnienia tego indywidualizmu wyłania się jego zdaniem społeczeństwo kontraktowe. Jest to związane $\mathrm{z}$ taką postacią indywidualizmu, który można nazwać hiperindywidualizmem. Jest on następstwem wcześniejszych faz indywidualizmu. Jego geneza sięga do ambiwalencji obecnej w kulturze burżuazyjnej. $Z$ jednej strony ta kultura wyzwalała jednostkę z więzów pochodzenia, rodziny, podporządkowania wspólnotom. Z drugiej strony kultura mieszczańska narzucała jednostce dyscyplinę po to, aby nauczyła się działać w sposób możliwie niezależny. Reakcją na tę strukturalną ambiwalencję jest albo zwrot $\mathrm{w}$ stronę konserwatywnych

${ }^{25}$ Tamże, s. 53-63.

${ }^{26}$ Por. J. Dewey, Individualism Old and New, Prometheus Books, Amsterdam-New York 1999. 
wartości i negacja idei wyzwolenia, albo koncentracja uwagi na opresyjnych własnościach kultury burżuazyjnej i poszukiwanie dróg wyzwolenia od obowiązującego modelu jednostki. Ta druga reakcja przybiera postać hieprindywidualizmu. Manifestuje się najwyraźniej w dążeniu do uwolnienia się od wszelkich restrykcji i normatywnych uregulowań. Hiperindywidualizm stwarza okazję do umacniania ideału jednostki wolnej od ograniczeń i niegodzącej się na „represjonowanie” przez społeczeństwo. „Represjonowanie” znaczy tu respektowanie konwenansów, utrwalonych wzorów, światopoglądów, i instytucji z rodziną małżeństwem włącznie ${ }^{27}$. Ten hiperindywidualizm ujawnia się dzisiaj w upowszechnianiu porozumień kontraktowych. W nich wszystkie roszczenia jednostki zostają skodyfikowane w postaci uprawnień.

Społeczeństwo kontraktowe poprzez system uprawnień powołuje do życia nowy układ więzi kolektywnych wynikających z kontraktów gwarantowanych ustawami i regulacjami kontrolowanymi przez państwo. W wyniku tego działanie na rzecz hiperindywidualizmu poprzez rozrastający się system kontraktów, ustaw i rożnych rodzajów kontroli społecznej powoduje się stopniową redukcję indywidualizmu ${ }^{28}$.

Indywidualizm samorealizacji polega, jak to już powiedziano, na przechodzeniu od podmiotowej autonomii do funkcji indywidualizmu, w którym dominuje funkcja celu. Transformacja tej funkcji indywidualizmu zawiera odniesienia do wielu procesów społecznych. Wspólną cechę stanowi tu tworzenie struktur instytucjonalnych, systemów wartości i wzorców biograficznych, które sprzyjają pojmowaniu jednostki jako autonomicznej agendy działania. Pod jego wpływem w krajach Europy Zachodniej dochodzi do dostosowania przepisów kodeksu cywilnego do postępów procesu indywidualizacji. W ten sposób utorowano drogę $\mathrm{ku}$ orientacjom normatywnym, które waloryzowały podążanie w życiu za własnymi pragnieniami i kierowanie się ocenami i normami, których uzasadnień poszukiwało się we własnych przekonaniach, wolnych od zewnętrznych wpływów ${ }^{29}$.

Przyjęcie takiej opcji światopoglądowej oznaczało kroczenie drogą nazywaną "dążeniem do autentyczności" lub "samorealizacji”. Dążenie do autentyczności obejmuje różnorodne decyzje i akty działania podmiotu.

${ }^{27}$ Por. P. Berger, Rewolucja kapitalistyczna. Pięćdziesiąt tez o dobrobycie, równości i wolności, Warszawa 1995, s. 191-195.

${ }^{28}$ Por. Z. Bokszański, dz. cyt., s. 56.

${ }^{29}$ Tamże, s. 57. 
Przebiegają one $w$ wielu obszarach aktywności. W pierwszej fazie indywidualizmu nie pojawiało się pojęcie autentyczności. Tamten indywidualizm w doświadczeniu jednostki był środkiem wiodącym do osiągnięcia określonego miejsca $\mathrm{w}$ społeczeństwie i posiadania dóbr. Wysiłkom tym towarzyszyła akceptacja standardów normatywnych podzielanych z innymi oraz liczne więzi wspólnotowe ${ }^{30}$.

Późna nowoczesność ujawniła przejściowy charakter tego stanu. Dynamika indywidualizacji przekroczyła kolejny próg. Przejawem tego był zanik formowania jednostek przez przynależności społeczne. On zawiera $\mathrm{w}$ sobie pierwiastki negatywnych zjawisk. Jest orientacją niezbędną $\mathrm{w}$ dobie intensywnie modernizującego się społeczeństwa kapitalistycznego, ale niebezpiecznie blisko sytuuje się wobec egoizmu. On sprawia, że obywatel izoluje się od zbiorowości i trzyma się na uboczu wraz ze swoją rodziną i przyjaciółmi. Stwarza w ten sposób swoje małe społeczeństwo na swój użytek. Egoizm wysusza źródła cnót, zabija też zalążek cnót społecznych. Po dłuższym czasie niszczy wszystkie inne cnoty i przeistacza się $\mathrm{w}$ egoizm.

Problem indywidualizmu kreatywnego podejmuje też Allan Bloom w Umysle zamkniętym. Najbardziej rzucają się cechą w społeczeństwie amerykańskim była otwartość na tolerancję, a wraz z nią relatywizm. W przekonaniu młodego pokolenia Amerykanów relatywizm stanowi jedyną możliwą postawę wobec różnorodnych roszczeń do prawdy, sposobów życia czy wartości kulturowych. Przeszłość była pełna nieprzejednanych obrońców prawdy. To ich zdaniem prowadziło do wojen, prześladowań ksenofobii i szowinizmu. Nie chodzi o to, aby pochylać się nad przeszłością i na nowo dociekać prawdy, ale raczej należy wyrzec się przekonania, że można znaleźć taką prawdę ${ }^{31}$.

Postawy otwartości, tolerancji i relatywizmu torowały sobie drogę do zdobycia dominującej pozycji w przekonaniach Amerykanów w ciągu XX wieku. Ponadto dzięki stałej obecności zachęt w myśli liberalnej do tworzenia warunków do maksymalnej samorealizacji on stopniowo nabierał coraz większego znaczenia. Powiększanie obszaru wolności wolnego od uregulowań społecznych i politycznych możliwe było kosztem roszczeń do moralnych pewników. Istniejące $\mathrm{w}$ człowieku pragnienie wolności rozwinęło się jeszcze bardziej. W tym ujęciu pełną wolność

${ }^{30}$ Tamże, s. 58.

${ }^{31}$ Por. A. D Bloom, Umyst zamknięty: o tym, jak amerykańskie szkolnictwo wyższe zawiodto demokracje i zubożyto dusze dzisiejszych studentów, Poznań 1997. 
można osiągnąć tylko wtedy, gdy nie istnieją żadne moralne i polityczne pewniki.

Taylor, zdaniem Bokszańskiego, docenia znaczenie indywidualizmu, który jest też krytykowany. Niesie on korzyści, które trzeba było okupić wieloma konsekwencjami. Pierwszą konsekwencją jest koncentracja na jednostce, która spowodowała, że życie ludzkie stało się mniej znaczące. Kolejnym przejawem negatywnych konsekwencji jest nasilenie się symptomów społeczeństwa permisywnego, rosnące znaczenie orientacji narcystycznej. Jednak zdaniem Taylora nie można odrzucić ideału samorealizacyjnego, bo on jest wpisany w tożsamość społeczeństwa zachodu. Jest to zdegradowany ideał, który sam w sobie jest bardzo wartościowy. Za samorealizacją kryje się ważny ideał moralny, wierności samemu sobie, który przez Taylora nazywany jest autentycznością. W centrum zagadnienia mieści się koncepcja indywidualizmu i jego funkcje w życiu zbiorowym. Z tych racji indywidualizm występuje jego zdaniem w dwóch odmianach. Pierwsza to ideał moralny, którego zasadniczym aspektem jest zasada samorealizacji. W drugim znaczeniu chodzi o zjawisko amoralne podobne do egoizmu. Narodziny indywidualizmu w tym drugim sensie wiąże się z upadkiem tradycyjnego ładu. Prowadzi to do anomii $\mathrm{i}$ indywidualnej walki o przetrwanie ${ }^{32}$.

Wszystkie modele indywidualizmu cechuje nie tylko to, że podkreślają one rolę jednostki, ale niosą ze sobą też pewien rodzaj wspólnoty. Indywidualizm zdegenerowany jest pozbawiony tego typu ideału wspólnoty. Indywidualizm pojmowany jako ideał moralny oferuje zawsze jakąś wizję ładu umożliwiającego współżycie jednostek. Znaczące filozofie indywidualizmy zawsze umieszczały na głównych miejscach jakieś wizje wspólnoty.

Indywidualizm rodzi też kulturę indywidualizmu. Chodzi tu o to, co tworzy warunki podtrzymuje i koryguje doświadczanie siebie przez jednostki tzn. „doświadczanie siebie w wolności i odpowiedzialności”. Indywidualizm jest też, jak podkreśla to M. Jacyno, jakąś formą uspołecznienia, czyli kulturowym projektem bycia w świecie ${ }^{33}$. Szczególnym przejawem tego jest personalizacja podmiotowości. Głównym zabiegiem jest tu „budowanie własnej tożsamości”. Główną strategią „budowania tożsamości" jest walka z instytucjami. Jest tu wielki obszar wypowiadanych im wojen czy przeprowadzanych rewolucji. Wyzwoleńczy styl życia

\footnotetext{
${ }^{32}$ Por. Z. Bokszański, dz. cyt., s. 61-62.

${ }^{33}$ Por. M. Jacyno, Kultura indywidualizmu, Warszawa 2007, s. 8.
} 
zakłada emancypację przez zracjonalizowanie i kontrolowane poszerzanie obszaru tego, co niekontrolowane ${ }^{34}$.

Kolejnym obszarem urzeczywistniania tej kultury jest „stwarzanie siebie". Temu służą różne nowe techniki samodyscypliny zwiększające autonomię. Zdobywanie kwalifikacji w tym zakresie staje się obowiązkiem. Sposób, w jaki jednostki doświadczają siebie, wyznaczony jest przez wartości i techniki służące regulowaniu świadomości siebie. Regulowanie doświadczenia siebie obejmuje możliwości i zdolności do tego się odnoszące. Chodzi tu takie zakresy doświadczania siebie, jak "starzania siebie", przechodzenie kryzysów, autotransformacji chorowania i umierania ${ }^{35}$.

Skutkiem „stwarzania siebie” są różne. Zauważa się, że upadek etosu protestanckiego doprowadził do wyeliminowania podstaw światopoglądowych scalających sens działania wobec siebie. Zaabsorbowanie sobą pozbawione metafizycznej perspektywy sprawia, że przyjmuje ono patologiczne formy. „Zarządzanie sobą" staje się coraz bardziej przedmiotem wolności moralnej i kwestią estetyki Wytworem kultury indywidualizmu ma być aspołeczna i narcystyczna jednostka. Jej relacje z innymi są bardzo nietrwałe i kruche, bowiem są pozbawione fundamentów. Narcystyczna osobowość zastąpiła tradycyjnego freudowskiego pacjenta. Narcystyczna osobowość jest klientem niekończącej się terapii. Narcyzm ten polega na uśmierzaniu leku i własnej niemocy przez fantazje o własnej omnipotencji. W istocie polega on na unikaniu "doświadczenia siebie”. Natomiast niepelny kontakt $\mathrm{z}$ sobą uniemożliwia nawiązanie relacji z innymi. Słaby kontakt $\mathrm{z}$ „własnym światem wewnętrznym” przekłada się też na słaby kontakt ze światem zewnętrznym. Unikanie wewnętrznego i zewnętrznego świata rodzi doświadczenie pustki i jałowości.

W kulturze indywidualizmu wielkiego znaczenia nabiera styl życia. Jest on wynikiem osobistych wyborów. Styl jest przestrzenią autoekspresji jednostki. Jest on traktowany jako sposób konstruowania siebie. Wypróbowuje się różne style życia i eksperymentuje się z nimi. Często przyjmuje to postać wprowadzania drobnych zmian we zachowaniu. Stylowi życia przypisuje się coraz większe znaczenie. Dzieje się tak z powodu niewystarczającego funkcjonowania tradycyjnie pojmowanej tożsamości. Staje się on wyrazem tego, kim jest jednostka. Autoeksperacja przez styl życia jest traktowana jako sposób poznawania siebie. Osoba z własnych wyborów dowiaduje się, kim ona jest. Styl życia bywa trakto-

\footnotetext{
34 Tamże, s. 186.

35 Tamże, s. 211.
} 
wany jako sposób emancypacji, jako szansa na indywidualne wyzwolenie się z różnych form zależności. Styl życia nie odnosi się do spraw fundamentalnych, lecz raczej nieistotnych. Zmiana stylu życia jest traktowana jako „zrobienie czegoś dla siebie”. Styl życia pozwala wybierać między młodością a starością, byciem czarnym lub białym, byciem imigrantem lub kimś miejscowym albo też pomiędzy kobietą a mężczyzną. Takie wybieranie jest interpretacją własnego doświadczenia. Przejawem stylu życia stają się tzw. „przebieranki”. Oznacza to w odniesieniu do klas niższych społeczeństwa np. ostentacyjne eksponowanie ubóstwa, wyzywającego i zarazem samobójczego stylu życia. Przejawia się to w sposobie ubierania, fryzurze, sporządzaniu agresywnego tatuażu i inne jeszcze przejawy. Przez to klasa niższa chce osiągnąć awans społeczny. Przez takie odgrywanie niska pozycja społeczna zostaje osobiście wybrana ${ }^{36}$.

W kulturze indywidualizmu widoczne jest nasilanie się zjawiska ryzyka. Nowoczesność niesie ze sobą wzrost powiązań między ludźmi, nowe sposoby organizacji społeczeństwa. Tworzą się też nowe sytuacje, w których coraz trudniej jest osobie przewidzieć konsekwencje własnych działań. Pojawia się więc ryzyko. Ma ono coraz bardziej charakter masowy. Podejmuje się próby jego kontroli. Jest ono często niewidoczne, a zarazem powszechne. Coraz częściej ma wymiar globalny. Jego przykładem jest choćby ocieplenie klimatu. Cechuje się ono tym, że nie można nad nim zapanować. Ono powoduje, że jednostka jest na nie skazana. Odpowiedzią osoby na tego typu ryzyko jest indywidualna odpowiedzialność i indywidualna strategia jego unikania. Styl życia nabiera tu charakteru kontroli ryzyka podejmowanego przez jednostki ${ }^{37}$. Podkreśla się konieczność bycia np. świadomym konsumentem, który nie zwiększa ryzyka ocieplenia klimatu.

Prywatyzacja ryzyka dokonuje się w kulturze indywidualizmu przez medykalizację. Polega ona, zdaniem M. Jacyno, na promowaniu idei higienicznego i zdrowego życia. W wyniku tego kuchnie i łazienki upodabniają się do laboratorium, gdzie zwykłe kąpiele stają się ważnym zabiegiem leczniczym. Idee medyczne nadają nowy sens od dawna stosowanym praktykom zdrowotnym. Medykalizacja ryzyka pociąga za sobą medykalizację życia. Ona zaś przyczynia się do tego, że zdrowie, młodość, sprawność stają się niemal absolutnymi wartościami ${ }^{38}$. Medykalizacja po-

\footnotetext{
36 Tamże, s. 56-62.

37 Tamże, s. 88-91.

38 Tamże, s. 92-95.
} 
woduje, że kult natury i naturalność idą w parze z walką z naturalnymi koniecznościami, jak starzenie się, osłabienie odporności i śmierć39.

Człowiek żyje więc w obliczu ryzyka. To zaś jest źródłem podziałów i nowego zróżnicowania społecznego. Jednostki mają zróżnicowane szanse kontroli ryzyka. W społeczeństwie pojawiają się nowe podziały ze względu na większe czy mniejsze możliwości jego kontroli. Rodzą się też nowe formy solidarności oparte na podobnej ocenie ryzyka. W społeczeństwie ryzyka niechęć, a nawet nietolerancję budzą przede wszystkim ci, którzy mają środki, by kontrolować ryzyko. W takich okolicznościach style życia przyjmują funkcje postaw światopoglądowych. W wyniku tego różne style życia różne style życia prezentują różne stopnie politycznego zaangażowania i wykazują różny stopień gotowości przekształcania się w opcje polityczne ${ }^{40}$. Niektóre style życia przechodzą proces instytucjonalizacji. Zdobywają też wyraźne rytuały. Mają one swój „miejsca pielgrzymkowe”, uprzywilejowane dyscypliny sportowe, kultową literaturę. W nich wyraźnie jest dostrzegalne silne pragnienie powrotu do natury, a także dążenie do autoekspresji siebie przez styl życia ${ }^{41}$.

W kulturze indywidualizmu pojawia się dążenie do panowania nad życiem. Przejawem życia w nowoczesnym społeczeństwie jest metafora „żelaznej klatki”. Ta „żelazna klatka” jest synonimem życia w uporządkowanym świecie, w którym wszystko jest urządzone a inicjatywa i spontaniczność są zbędne. Ta metafora podkreśla możliwość oddania się biurokratycznym instytucjom, które wszystko w życiu porządkują. Metafora ta podkreśla też władzę biurokracji nad jednostką. Biurokracja realizuje swoją władzę przez wprowadzanie coraz większego porządku w życie społeczne jednostki. Tym samym coraz bardziej ogranicza jej wolność. Osoba ma coraz wyraźniejsze odczucie wszechobecności systemu. Wszechobecny system tworzy doświadczenie życia w świecie, który wymyka się możliwościom ludzkiej kontroli. „Żelazna klatka” przeobraża się w „wygodną celę". Staje się miejscem ucieczki przed chaosem świata. Osoba zaczyna uciekać od wolności jako możliwości realizacji dobra. Ucieczka od wolności, od możliwości działania jest efektem mnożenia się w życiu społecznym coraz liczniejszej rzeszy ekspertów. Oni zaś stopniowo zaczynają przejmować kontrolę nad życiem jednostki. Zarazem

\footnotetext{
39 Tamże, s. 95-96.

40 Tamże.

${ }^{41}$ Tamże, s. 97.
} 
„wygodna cele” przynosi rozkosz rozumianą jako chwile pełne szczęścia na własnej sofie strawione na oglądaniu telewizji ${ }^{42}$.

Racjonalizacja życia poprzez wzrost znaczenia biurokracji miała przynieść skutki pozytywne. Tymczasem zwraca się przeciw niej samej. Umożliwia to panowanie bezosobowej biurokracji w wielu sferach życia. Nad życiem jednostki zaczynają dominować politycy, którzy przez regulacje prawne wprowadzające coraz większe uporządkowanie w życie jednostki powodują coraz głębsze podporządkowanie jej systemowi. Do roli tych osób kontrolujących jednostkę zalicza się też różnych ekspertów. Oni starają się interpretować okoliczności i procesy życia społecznego oraz badać zjawiska i procesy pojawiające się w populacji. Wreszcie życie jednostki jest racjonalizowane przez kontrolowanie warunków, w których człowiek żyje i eliminowanie niebezpieczeństw dla życia i zdrowia. Stąd taką racjonalizującą rolę odgrywa medykalizacja życia. Szczególne znaczenie $w$ tym zakresie przypisuje się psychologii. W starym porządku świata zagrażająca życiu choroba prowokowała pytanie o sens życia. Odpowiedzi zaś na temat sensu życia dostarczała religia. Natomiast w społeczeństwie ogarniętym indywidualizmem miejsce religii coraz powszechniej zajmuje psychologia. Ona stara się pomagać jednostce doświadczającej leku wobec życia $^{43}$.

W kulturze indywidualizmu samorealizacji nie jest celem budowanie więzi z innymi czy z Innym, ale raczej odwaga do ich porzucania a nawet niszczenia tych związków. Zdolność do prowokowania rozstań jest testem samowystarczalności, asertywności i odwagi do bycia sobą. Budowanie relacji z innymi widziane jest z perspektywy kontraktu. Stąd perspektywa wspólnego zamieszkania, wspólnego kupna mieszkania, posiadania dzieci traktowana jest jako rodzaj testu dla związku. Test ten polega na szacowaniu korzyści i strat, jakie trzeba zapłacić. Jeśli ten bilans jest korzystny, to wówczas Tak pojmowana relacja miłości jest przejawem relacji podobnych do kultury przedsiębiorczości ${ }^{44}$. Jednostka jest też coraz bardziej kontrolowana przez państwo i stanowione prawo. Człowiek żyje coraz bardziej w "ż̇elaznej klatce”, doświadczając coraz boleśniej własnej samotności.

\footnotetext{
${ }^{42}$ Tamże, s. 111-114.

${ }^{43}$ Tamże, s. 115-134.

${ }^{44}$ Tamże, s. 212-227.
} 


\section{OCENA INDYWIDUALIZMU Z PUNKTU WYCHOWANIA CHRZEŚCIJAŃSKIEGO}

Zjawisko indywidualizmu nade wszystko kultura indywidualizmu ma znaczenie dla wychowania. Jest ono wyzwaniem także dla wychowania chrześcijańskiego. Indywidualizm niesie ze sobą inną wizję relacji jednostki do wspólnoty. Wychowanie chrześcijańskie respektuje indywidualny rozwój cech jednostki. Podkreśla jednak, że człowiek rozwija się najpełniej we wspólnocie Kościoła. Stąd w katechezie wśród celów wymienia się między innymi wychowanie do wspólnoty, dąży się do kształtowania poczucia odpowiedzialności za chrześcijańską wspólnotę. Wychowuje się tu do zwiastowania Ewangelii. Kościół czyni to w imieniu Chrystusa. Zatem wychowuje się do głoszenia Ewangelii w łączności z Kościołem. To zaś może być niezrozumiałe dla osób i środowisk ukształtowanych pod wpływem indywidualizmu. Skoro indywidualizm prowokuje ludzi do walki ze wszelkimi instytucjami w imię autonomii jednostki, to to odnosi się także do Kościoła. Stąd ostrze ataku nakierowuje się przeciwko nauczaniu moralnemu Kościoła.

Również wizja człowieka, jaką przedstawia i realizuje Kościół, może być niezrozumiała dla ludzi ukształtowanych przez indywidualizm samorealizacji postulujący wolność od jakichkolwiek zależności od norm moralnych. Kościół proponuje pracę nad sobą opartą na wartościach Ewangelii. Natomiast w ideale samorealizacji siebie będzie niezrozumiałe kształtowanie siebie na wzór Jezusa Chrystusa.

W wychowaniu chrześcijańskim przyjmuje się, że człowiek obdarzony jest wadami i zaletami. Praca nad sobą zmierza tu do pokonania swoich słabości i rozwoju pozytywnych cech. Natomiast rekonstrukcja obrazu siebie, jaką proponuje indywidualizm jest $\mathrm{w}$ istocie ucieczką od prawdy o sobie samym i prowadzi osobę do posługiwania się mechanizmami obronnymi jak mechanizm racjonalizacji. Tym samym pogłębia trudności na drodze do poznania siebie. Może więc sprawiać, że w duszpasterstwie będziemy spotykać ludzi doświadczających pustki duchowej, doświadczających poczucia bezsensu życia albo szukających sensu życia w posiadaniu i gromadzeniu różnych dóbr.

Chrześcijaństwo proponuje wychowanie człowieka przez odwołanie się do jego sumienia, które kieruje się zasadami moralnymi czerpanymi z Objawienia. Natomiast indywidualizm samorealizacji akceptuje, że nie ma zasad moralnych zawsze obowiązujących. Tym samym opowiada się za etyką sytuacyjną. W indywidualizmie przyjmuje się też, że nie ma 
obiektywnej prawdy i nie można jej poznać. Tym samym przyjmuje się, że moje subiektywne przekonanie, co jest prawdą, prowadzić będzie do wybierania z depozytu wiary tylko tych prawd wiary i zasad moralnych, które są dla mnie wygodne. Takie postawy młodzieży potwierdzają też niektóre badania. Ujawniają one narastający wśród młodego pokolenia permisywizm moralny. Wyraża się on w niemal powszechnej akceptacji najogólniejszych norm moralnych i braku w świadomości moralnej wynikających z tych ogólnych zasad szczegółowych norm moralnych. Zauważa się także, że współczesna młodzież coraz częściej rozdziela w swojej świadomości akceptację religijności od moralności wynikającej z religii i opowiada się dość często za indywidualnym kodeksem moralnym ${ }^{45}$.

Chrześcijaństwo wychowuje człowieka do życia we wspólnocie z innymi, do akceptacji drugiego człowieka. To stanowi fundament budowania więzi $\mathrm{z}$ innymi, przede wszystkim więzi w małżeństwie. Tymczasem indywidualizm $\mathrm{w}$ imię autonomii siebie prowokuje osoby do budowania płytkich relacji z innymi. W imię asertywności i potwierdzania siebie proponuje zrywanie więzi z innymi. To skutkuje nietrwałością więzi małżeńskich i rodzinnych.

W upowszechnianiu postaw preferowanych przez indywidualizm samorealizacji istotną rolę odgrywają środki masowego przekazu. Obecnie ich powszechność szybko upowszechnia idee indywidualizmu. Stąd zarówno na katechezie, jak i w duszpasterstwie należy się liczyć z postępującym procesem indywidualizacji. Wydaje się że ta sytuacja stwarza też wspólnocie Kościoła szanse prowadzenia dyskursu z ideałami indywidualizmu. Może przekazywać zarówno pozytywne przesłanie jak też ostrzegać przed konsekwencjami indywidualizmu kreacyjnego oraz pokazywać chrześcijańską wizję odniesienia osoby do społeczeństwa. Taką możliwość stwarza także lekcja religii w szkole. Ona stwarza możliwość kontaktu z młodymi , którzy budują wizję własnego człowieczeństwa. Treści katechetyczne dają wiele okazji do budowania i pogłębiania własnej tożsamości katechizowanych. Lekcja religii może pomagać także w osiąganiu autonomii moralnej i w absolutyzowaniu wartości religijnych w systemie wartości poszczególnych osób. Na katechezie często będzie można spotkać osoby ogarnięte ideami indywidualizmu i doświadczające zagubienia i pustki duchowej. Katecheza zatem umożliwia kontynuowanie relacji z tą młodzieżą w duszpasterstwie. Stąd bardzo ważne

${ }^{45}$ Por. H. Świda-Ziemba, Permisywizm moralny a postawy polskiej młodzieży, w: Kondycja moralna społeczeństwa polskiego, red. J. Mariański, Kraków 2002, s. 440-452. 
będzie stwarzanie im możliwości doświadczania autentycznej wspólnoty chrześcijańskiej żyjącej wartościami wypływającymi z wiary. Ważne jest, aby oni widzieli świadectwo takiej wspólnoty w życiu społecznym. Dla dojrzewających osób, które poszukiwać będą głębszych wartości, pomocą mogą być centra duchowości chrześcijańskiej, czy też centra woluntariatu promującego idee wspólnotowego działania inspirowanego wartościami chrześcijańskimi.

\section{CHRISTIAN EDUCATION IN CONSIDERATION OF THE CULTURE OF INDIVIDUALISM}

\section{SUMMARY}

Individualism is a term important for Christian education. The understanding of individualism took a long way of development. Its importance used in sociology helps to understand the broad social context of Christian education better. It is usually said about egalitarian individualism and romantic individualism. The first emphasizes the crucial equality between individuals. It is emphasized here that the individual goals can be achieved by compliance with the moral standards and fundamental principles. Such a belief mobilized to the self-discipline and subordination to the will of the majority. The romantic individualism was expressed mainly in the discovery and manifestation of its own originality. The single individual did not seek here the common rights and duties. It created the world of its own subjectivity often beyond the sphere of community life, often against the existing social or moral order. The understanding of individualism is constantly developing. Currently, in the age of the postmodern society, it is emphasized, according to some researchers, that it leads to the formation of the contractual society. It manifests clearly in the quest to release the individual from any restrictions and regulatory frameworks. Through a system of allowances, the contractual society brings to life a new system of collective relationships which result from the contracts guaranteed by regulations and laws controlled by the state. In the modern individualism one is no longer formed by social belonging. The citizen, shaped in this way, often isolates from the community and stays aside together with his family and friends. Under the influence of individualism the focus on the individual increases. Thus, human life has become less significant. A phenomenon of permissiveness is growing in the individualistic society. In a society in the age of post modernity, the culture of individualism increases. It manifests itself in the "personalization of subjectivity", "building your own identity by creating yourself". The effects of "self creation" are very different. It is noted that there has been a decline of the Protestant ethos in Western society. This led to the elimination of philosophical foundations uniting the sense of acting towards each other. At the same time focusing on yourself and the lack of metaphysical perspective causes that more and more pathological forms of 
referring to yourself appear. "Self-management 'is becoming more a matter of moral freedom and aesthetics. The antisocial and narcissistic individual is becoming the product of culture of individualism. Its relationship with others is very unstable and fragile. Such a person can not build deep relationship with others. In a culture of individualism one pays attention to the "lifestyle as a form of self expression". The lifestyle saturated with individualism provokes risk on a massive scale. A human being tries to reduce the emerging risk by the "medicalisation of life." Living in the society overwhelmed by individualism is becoming more rational. The increasing rationalization of life brings the rise of bureaucracy that is increasingly trying to control the individual.

The widespread individualism in the society brings the consequences for education. It also affects the Christian education. It brings a different vision of the relationship of an individual with the community. It also excessively exposes the role of the individual. Christian education respects the individual development of the features of the single individual. It emphasizes, however, that a man develops most fully in the community of the Church. Individualism, in the name of freedom of the individual, often provokes the fight with all institutions. It also often refers to the Church. Thus, the attack is directed against the moral teaching of the Church. The Church encourages self-improvement and overcoming the personal weaknesses . Whereas the ideology of individualism allows the individual to recognize constantly their own perfection. It makes a person under its influence try to adapt to the conditions of life. Christianity more teaches to live in the community. Whereas the ideology of individualism forms a person not capable of forming relationship with others. The ideology of individualism has spread through the media and shapes attitudes strongly. It requires great effort on the part of Christian education to oppose the dangers carried by modern manifestations of culture of individualism. 